\title{
PENGARUH CITRA KULINER TRADISIONAL KHAS KAILI TERHADAP KEPUTUSAN PEMBELIAN PADA KAWASAN WISATA ANJUNGAN PANTAI TALISE DI KOTA PALU
}

\author{
Moh.Rifki. A \\ Suardi \\ Nirwan \\ Program Studi Manajemen, Fakultas Ekonomi, Universitas Tadulako \\ E-mail: mohxrifkitello@yahoo.co.id nirwan.fe.untad@gmail.com
}

\begin{abstract}
The Central Sulawesi government is now starting to increase tourism potential in each of its regions to increase local revenue. In tourism the most spent expenditure is food and beverage where there are several places that tourists can visit to enjoy culinary tourism, one of which is the Talise Beach Pavilion tourist area that provides traditional culinary tours. This study aims to find out and analyze the influence of traditional traditional culinary imagery on purchasing decisions in the tourist area of Talise Beach Pavilion. This type of research is quantitative. Medote research is descriptive causal. The sample used is as many as 60 respondents with the sampling form using incidental sampling techniques. Data analysis method used is multiple linear regression analysis method. The results of this study indicate that the dimensions of the image which consist of strength, uniqueness, and excellence simultaneously have a significant effect on purchasing decisions with a value of Sig $F=0,000$ and have a large influence of 40.6\%. As well as partially the image dimensions have a significant effect on purchasing decisions.
\end{abstract}

Keywords: Image dimensions which consist of strength, uniqueness, excellence influence purchasing decisions.

\begin{abstract}
ABSTRAK
Pemerintah Sulawesi Tengah kini mulai meningkatkan potensi pariwisata pada setiap daerahnya untuk meningkatkan pendapatan asli daerah. Pada pariwisata pengeluaran yang paling banyak dikeluarkan yaitu food and beverage dimana ada beberapa tempat yang dapat dikunjungi wisatawan untuk menikmati wisata kuliner salah satunya yaitu kawasan wisata Anjungan Pantai Talise yang menyediakan wisata kuliner tradisional. Penelitian ini bertujuan untuk mengetahui dan menganalisis pengaruh citra kuliner tradisional khas kaili terhadap keputusan pembelian pada kawasan wisata Anjungan Pantai Talise. Jenis penelitian ini adalah kuantitatif. Medote penelitian adalah deskriptif kausal. Sampel yang digunakan yaitu sebanyak 60 responden dengan bentuk pengambilan sampel menggunakan teknik Sampling Insidental. Metode analisis data yang digunakan adalah metode analisis regresi linear berganda. Hasil penelitian ini menunjukkan dimensi citra yang terdiri dari kekuatan, keunikan, dan keunggulan secara serempak berpengaruh signifikan terhadap keputusan pembelian dengan nilai Sig F = 0,000 dan memiliki besar pengaruh sebesar $40,6 \%$. Serta secara parsial dimensi citra berpengaruh signifikan terhadap keputusan pembelian.

Kata Kunci: Dimensi citra yang terdiri dari kekuatan, keunikan, keunggulan mempengaruhi keputusan pembelian.

\section{PENDAHULUAN}

Pemerintah Sulawesi Tengah kini mulai menigkatkan pariwisata pada setiap daerah, hal ini di dukung berdasarkan UU No 10 Tahun 2009 yang meyebutkan bahwa keberadaan obyek wisata pada suatu daerah akan sangat mengutungkan antara lain dapat meningkatkan pendapatan asli daerah, meningkatkan taraf hidup masyarakat, memperluas lapangan pekerjaan, dan meningkatkan rasa cinta pada lingkungan.
\end{abstract}


Menurut Cooper (dalam Prasiasa, 2013:52) dalam industry pariwisata terdapat beberapa komponen yaitu atraksi, aksesibilitas, amenity, dan ancillary yang mengurus kepariwisataan. Beberapa komponen tersebut pengeluaran cukup banyak yang dilakukan oleh wisatawan yaitu pada amenity yang meliputi food and beverage. Kondisi tersebut didukung dengan terdapat restoran dan juga rumah makan yang menyediakan berbagai macam jenis kuliner yang ada di Sulawesi Tengah.

Kuliner pada pariwisata berdampak positif dalam kegiatan ekonomi, hal tersebut dapat dibuktikan dengan hadirnya berbagai macam restoran dan rumah makan yang menyediakan berbagai macam kuliner khas Kota Palu. Ada beberapa tempat kuliner yang dapat dikunjungi wisatawan untuk dapat menikmati wisata kuliner seperti pada restoran, rumah makan, dan café yang tedapat berbagai kuliner, tetapi dari sekian banyak tempat kuliner yang tersedia terdapat salah satu tempat yang wajib dikunjungi oleh wisatawan yaitu kawasan wisata Anjungan Pantai Talise dimana kawasan ini menjadi obyek wisata kuliner yang menyediakan berbagai macam jenis kuliner tradisional khas daerah Kota Palu.

Kawasan wisata Anjungan PantainTalise menyediakan berbagai macam kuliner tradisional khas Kota Palu yang meliputi Palumara, Uwempoi, Utadada, Duosole, Dange Sagu, Uta Kelo, Saraba, dan Bakso Kuah Kaledo, dimana kuliner tradisional khas kaili memiliki cita rasa yang khas dan tampilan yang unik, serta harga yang terjangkau dan penamaan makanan yang unik yang dapat membuat wisatawan penasaran akan kuliner khas tradisional khas kaili. Salah satu juga yang dapat menambah minat wisatawan untuk berkunjung yaitu dengan mengoptimalkan sebuah citra.

Melihat uraian yang terdapat diatas maka penulis tertarik untuk melakukan penelitian yang dituangkan dalam judul: Pengaruh Citra Kuliner Tradisional Khas Kaili Terhadap Keputusan Pembelian Pada Kawasan Wisata Anjungan Pantai Talise Di Kota Palu. Adapun tujuan dilakukannya penelitian ini yaitu, untuk mengetahui pengaruh variabel dimensi citra yang terdiri dari kekuatan, keunikan, dan keunggulan secara serempak berpengaruh signifikan terhadap keputusan pembelian.Untuk mengetahui pengaruh variabel dimensi citra yang terdiri dari kekuatan, keunikan, dan keunggulan secara parsial berpengaruh signifikan terhadap keputusan pembelian.

\section{KAJIAN LITERATUR DAN PENGEMBAGAN HIPOTESIS}

Sukardi (dalam Andayani, 2013:2) mengungkapkan pengertian pariwisata adalah "Pariwisata dalam artian yang semurni-murninya adalah untuk bersenang-senang dan dinikmati dalam waktu senggang. Akibat dari gejala atau fenomena dan hubungan tersebut, oleh penduduk setempat muncul industri pariwisata".

Boyd, et, al (2000:4) mengatakan bahwa pemasaran adalah suatu proses sosial yang melibatkan kegiatan-kegiatan penting yang memungkinkan individu dan perusahaan mendapatkan apa yang mereka butuhkan dan inginkan melalui pertukaran dengan pihak lain untuk mengembangkan hubungan pertukaran.

Informasi dan tekanan sosial mempengaruhi kebutuhan, keinginan, evaluasi, dan perferensi produk atau merek konsumen. Pengaruh sosial terutama muncul ketika konsumen membeli barang atau jasa yang secara sosial dianggap memiliki keterlibatan tinggi. Pengaruh sosial yang mempengaruhi keputusan pembelian konsumen mencakup kebudayaan, subkebudayaan, kelas sosial, kelompok referensi, dan keluarga (Boyd, et al. 2000).

Danang Sunyoto (2012:255) mendefinisikan Perilaku Konsumen adalah sebagai kegiatan-kegiatan individu yang secara langsung dapat terlibat dalam mendapatkan dan mempergunakan barang-barang/jasa termasuk didalamnya proses pengambilan keputusan pada persiapan dan penentuan kegiatan-kegiatan tersebut. Ada dua elemen penting dalam perilaku konsumen yaitu proses pengambilan keputusan dan kegiatan fisik, yang semua ini melibatkan individu dalam menilai, mendapatkan, dan mempergunakan barang/jasa secara ekonomis.

Citra merupakan keseluruhan persepsi terhadap produk atau merek yang dibentuk dari informasi dan penggalan masa lalu terhadap produk atau merek itu (Sutisna, 2003:83). Definisi lain citra adalah jumlah 
dari gambaran-gambaran, kesan-kesan, dan keyakinan-keyakinan yang dimiliki oleh seseorang terhadap suatu obyek (Sutisna, 2003:83).

Menurut Kotler dan Keller (2005:359) Citra adalah cara konsumen mempersepsikan atau memikirkan suatu produk yang di pengaruhi oleh banyak faktor.

Suryani (2008:13) berdasarkan tujuan pembelian, konsumen dapat digolongkan menjadi konsumen akhir dan konsumen organisasional. Konsumen akhir adalah konsumen yang menggunakan produk atau jasa untuk keperluan individu untuk dikonsumsi. Sedangkan konsumen organisasional menggunakan produk untuk keperluan kelompok atau bisnis tertentu untuk memperoleh keuntungan.

Menurut Kotler dan Keller (2007:234) proses pembelian yg spesifik terdiri dari urutan kejadian sebagai berikut: pengenalan masalah, pencarian informasi, evaluasi alternatif, keputusan pembelian, dan perilaku pasca pembelian. Tugas pemasar yaitu memahami perilaku pembeli pada tiap tahap dan pengaruh apa yg bekerja dalam tahap-tahap tersebut.

\section{Kerangka Pemikiran}

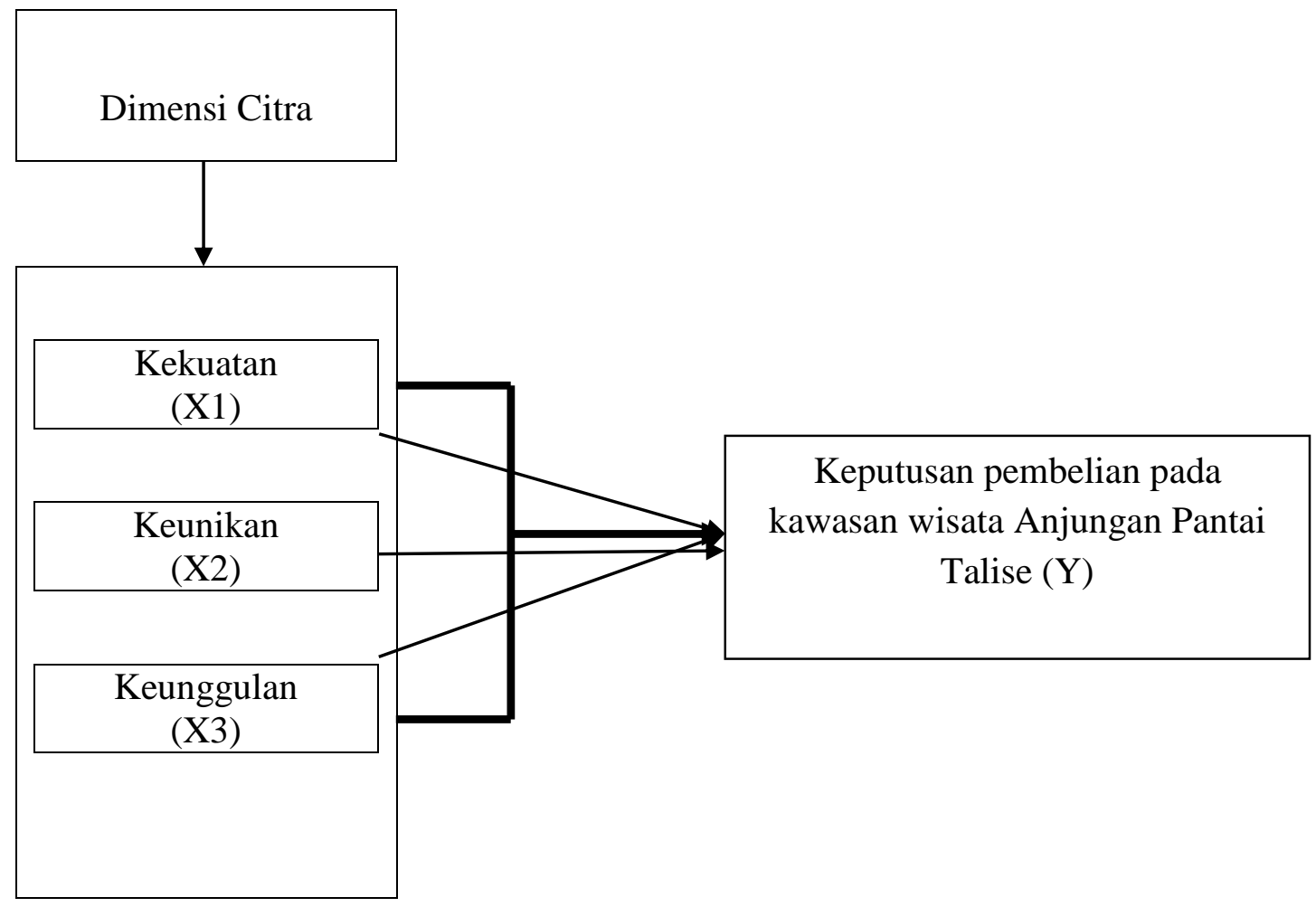

Gambar 1

Kerangka Pemikiran

\section{Hipotesis}

Hipotesis merupakan jawaban permasalahan sementara yang bersifat dugaan dari suatu penelitian. Hipotesis dapat terbukti atau tidak terbukti setelah didukung oleh fakta-fakta dari hasil penelitian dilapangan. Hipotesis dalam penelitian ini adalah:

$\mathrm{H}_{1}$ :Citra yang terdiri dari kekuatan, keunikan, dan keunggulan secara serempak berpengaruh signifikan terhadap keputusan pembelian pada kawasan wisata Anjungan Pantai Talise di Kota Palu. 
$\mathrm{H}_{2}$ :Variabel kekuatan secara parsial berpengaruh signifikan terhadap keputusan pembelian pada kawasan wisata Anjungan Pantai Talise di Kota Palu.

$\mathrm{H}_{3}$ :Variabel keunikan secara parsial berpengaruh signifikan terhadap keputusan pembelian pada kawasan wisata Anjungan Pantai Talise di Kota Palu.

$\mathrm{H}_{4}$ :Variabel keunggulan secara parsial berpengaruh signifikan terhadap keputusan pembelian pada kawasan wisata Anjungan Pantai Talise di Kota Palu.

\section{METODE PENELITIAN}

Sumber data yang digunakan dalam penelitian ini yaitu sumber data primer dan sekunder. Data primer adalah data yang di peroleh langsung dari responden dengan cara membagikan kuesioner berkaitan dengan penelitian ini (konsumen yang berkunjung ke kawasan wisata Anjungan Pantai Talise dan menikmati kuliner tradisional khas kaili). Serta data sekunder berupa data yang sudah tersedia dan diperoleh dari pihak pengelolah kawasan wisata Anjungan Pantai Talise dan Dinas Pariwisata.

Metode Pengumpulan Data:

1. Observasi disebut juga metode pengamatan. Ringkasnya observasi merupakan pengumpulan data secara langsung dengan cara melakukan pencatatan terhadap apa yang di amati pada lokasi penelitian.

2. Wawancara adalah pengumpulan data dengan cara melalukan tanya jawab secara langsung dengan responden dan pihak pengelolah.

3. Kuesioner yaitu pengumpulan data dengan mengajukan daftar pertanyaan atau pernyataan secara tertulis kepada responden.

Pengujian Instrumen Penelitian

1. Uji Validitas

Ghozali (2013:52) uji validitas digunakan untuk mengukur sah atau valid tidaknya suatu kuesioner, suatu kuesioner dikatakan valid jika pertanyaan pada kuesioner mampu untuk mengungkapkan sesuatu yang akan diukur oleh kuesioner tersebut. Syarat minimum untuk dianggap memenuhi syarat adalah $\mathrm{r}=$ 0.3. Jadi, korelasi antara butir dengan skor total kurang dari 0.3 maka butir dalam instrument tersebut dinyatakan tidak valid. Sebaliknya, bila skor total sama dengan 0.3 atau lebih (paling kecil 0.3) maka instrumen tersebut dinyatakan valid.

2. Uji Reliabilitas

Sunyoto (2013:81) uji reliabilitas adalah alat untuk mengukur suatu kuesioner yang merupakan indikator dari variabel atau konstruk. Butir pertanyaan dikatakan reliabel atau handal apabila jawaban seseorang terhadap pertanyaan adalah konsisten. Pengukuran kehandalan butir pertanyaan dengan sekali menyebarkan kuesioner pada responden, kemudian hasil skornya diukur korelasinya antar score jawaban pada butir pertanyaan yang sama dengan bantuan komputer SPSS dengan fasilitas Cronbach Alpha $(\alpha)$. Suatu konstruk atau variabel dikatakan reliabel jika memberikan nilai Cronbach Alpha $>0.60$.

Berikut ini adalah hasil uji validitas dan reliabilitas atas item pertanyaan yang terdapat dalam kuesioner penelitian terhadap variabel independen kekuatan, keunikan, keunggulan dan variabel dependen keputusan pembelian. Adapun hasilnya disajikan dalam tabel 1 validitas dan reliabilitas instrumen penelitian berikut:

Tabel 1

Hasil Uji Validitas dan Reliabilitas Instrumen Penelitian

\begin{tabular}{|c|c|c|c|c|c|}
\hline Variabel & Item & $\begin{array}{c}\text { Total } \\
\text { Correlation }\end{array}$ & Ket & $\begin{array}{c}\text { Cronbach } \\
\text { Alpha }\end{array}$ & Ket \\
\hline
\end{tabular}


JURNAL ILMU MANAJEMEN UNIVERSITAS TADULAKO

Vol. 5, No. 3, September 2019, p. 265 - 274

ISSN : 2443-3578 (On Line) / ISSN : 2443-1850 (Print)

\begin{tabular}{|c|c|c|c|c|c|}
\hline Variabel & Item & $\begin{array}{c}\text { Total } \\
\text { Correlation }\end{array}$ & Ket & $\begin{array}{c}\text { Cronbach } \\
\text { Alpha }\end{array}$ & Ket \\
\hline Kekuatan & X1.1 & 0,585 & Valid & & \\
(X1) & X1.2 & 0,398 & Valid & 0,639 & Reliabel \\
& X1.3 & 0,440 & Valid & & \\
\hline Keunikan & X2.1 & 0,455 & Valid & \multirow{2}{*}{ Reliabel } \\
(X2) & X2.2 & 0,455 & Valid & 0,625 & \\
\hline Keunggulan & X3.1 & 0,815 & Valid & & \\
(X3) & X3.2 & 0,829 & Valid & \multirow{2}{*}{0,861} & Reliabel \\
& X3.3 & 0,613 & Valid & & \\
\hline & Y1 & 0,325 & Valid & & \\
Keputusan Pembelian & Y2 & 0,453 & Valid & & \\
(Y) & Y4 & 0,512 & Valid & \multirow{2}{*}{0,701} & Reliabel \\
& Y5 & 0,350 & Valid & & \\
\hline & Y6 & 0,483 & Valid & & \\
\hline
\end{tabular}

Sumber: Data diolah tahun 2018

Berdasarkan hasil uji validitas dan reliabilitas diperoleh bahwa seluruh variabel memiliki koefisien Cronbach Alpha (a) lebih besar dari 0,60 sehingga berdasarkan syarat minimum reliabilitas lebih besar dari 0,60 maka seluruh variabel yang digunakan adalah reliabel dan dapat digunakan dalam penelitian ini. Sedangkan uji validitas terhadap seluruh variabel juga menunjukan nilai koefisien korelasi yang lebih besar dari 0,30 sehingga item pernyataan yang ada valid untuk digunakan.

3. Uji Asumsi Klasik

a. Uji Multikolienaritas, digunakan untuk menguji apakah model regresi ditemukan adanya kolerasi antara variabel bebas independen. Uji multikolinieritas dapat dilakukan dengan cara melihat VIF (Varlance Inflation Faktors) Jika tolerance $\geq 0.10$ atau sama dengan nilai VIF $\leq 10$ maka menunjukan tidak terjadi multikolinieritas, dan sebaliknya (Ghozali, 2013:105).

b. Uji Hetersokedastisitas, Ghozali (2013:139) menyatakan uji heteroskedastisitas yaitu untuk menguji apakah dalam model regresi terjadi ketidaksamaan variance dari residual satu pengamatan ke pengamatan yang lain. Dasar pengambilan keputusan, jika tidak ada pola yang jelas, serta titik-titik menyebar diatas dan dibawah angka nol pada sumbu Y, maka tidak terjadi heteroskedastisitas.

c. Uji Normalitas, digunakan untuk menguji apakah dalam sebuah model regresi variabel (pengganggu) dependen dan independen atau keduanya memiliki distribusi normal (Ghozali, 2013:160). Dasar pengambilan keputusan, jika data yang menyebar di sekitar garis diagonal dan mengikuti arah garis diagonal, maka model regresi memenuhi asumsi normalitas.

4. Regresi Linear Berganda

Adapun formulasi model alat analisis statistik yang digunakan dalam penelitian ini, adalah sebagai berikut (Sugiyono, 2012:243). 


$$
Y=a+b_{1} X_{1}+b_{2} X_{2}+\cdots+b_{n} X_{n}
$$

Dimana:

$$
\begin{aligned}
& \mathrm{Y} \quad=\text { Variabel Dependen } \\
& \mathrm{a} \quad=\text { Konstanta } \\
& \text { b1-bn } \quad=\text { Koefisien Regresi } \\
& \mathrm{X} 1-\mathrm{Xn}=\text { Variabel Independen }
\end{aligned}
$$

formulasi regresi linier berganda diatas, jika dimasukkan kedalam variabel penelitian ini maka diperoleh suatu persamaan regresi linier berganda sebagai berikut:

$$
Y=a+b_{1} X_{1}+b_{2} X_{2}+b_{3} X_{3}
$$

Dimana:

$$
\begin{array}{ll}
\mathrm{Y} & =\text { Keputusan Pembelian } \\
\mathrm{X}_{1} & =\text { Kekuatan } \\
\mathrm{X}_{2} & =\text { Keunikan } \\
\mathrm{X}_{3} & =\text { Keunggulan } \\
\mathrm{a} & =\text { Konstanta } \\
\mathrm{b}_{1}-\mathrm{b}_{3} & =\text { Koefisien Regresi }
\end{array}
$$

\section{HASIL DAN PEMBAHASAN}

Penelitian ini menggunakan analisis regresi linear berganda dengan tujuan untuk menguji pengaruh citra terhadap keputusan pembelian, lebih jelasnya hasil analisis regresi linear berganda dapat dilihat pada tabel 2 berikut:

Tabel 2

Hasil Uji Regresi Linear Berganda

\begin{tabular}{|c|r|r|c|c|}
\hline \multicolumn{5}{|c|}{ Dependen Variabel Y = Keputusan Pembelian } \\
\hline \multirow{2}{*}{$\begin{array}{c}\text { Variabel } \\
\text { Independen }\end{array}$} & \multicolumn{2}{|c|}{$\begin{array}{c}\text { Unstandardized } \\
\text { Coefficients }\end{array}$} & $\begin{array}{c}\text { Standardized } \\
\text { Coefficients }\end{array}$ & \multirow{2}{*}{ Sig. t } \\
\cline { 2 - 4 } & B & Std. Error & Beta & \\
\hline (Constant) &, 320 &, 720 & & \multirow{2}{*}{, 659} \\
\hline
\end{tabular}


JURNAL ILMU MANAJEMEN UNIVERSITAS TADULAKO

Vol. 5, No. 3, September 2019, p. 265 - 274

ISSN : 2443-3578 (On Line) / ISSN : 2443-1850 (Print)

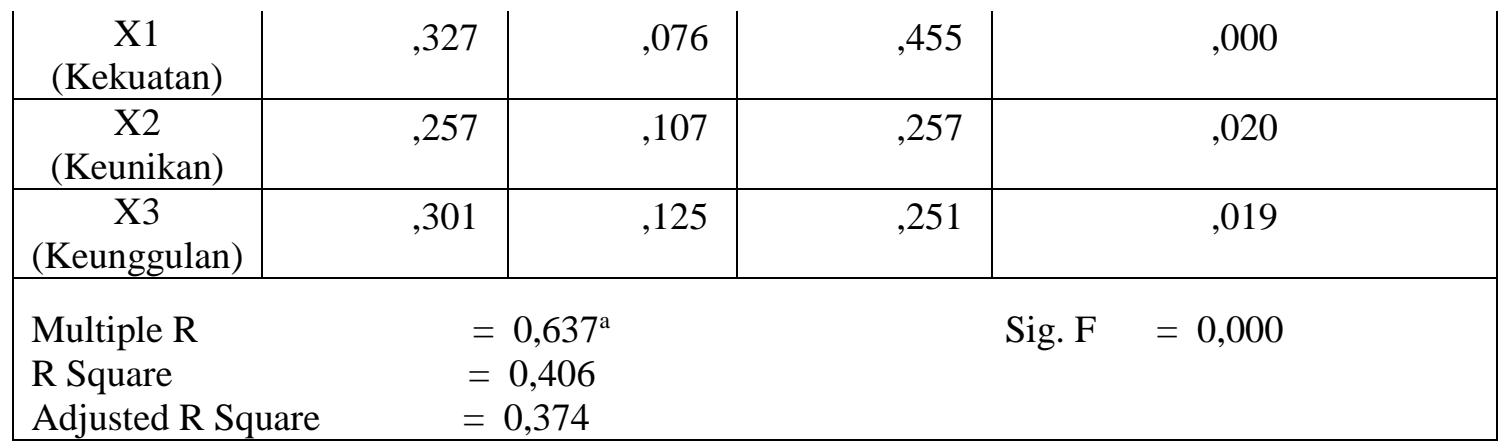

Sumber: Data diolah tahun 2018

Berdasarkan tabel 2 di atas, dapat di tulis dalam bentuk persamaan regresi linear berganda. Lebih jelasnya bentuk persamaan tersebut dapat dilihat sebagai berikut:

$$
Y=0,320+0,327 X_{1}+0,257 X_{2}+0,301 X_{3}
$$

Berdasarkan penjabaran di atas menunjukkan bahwa, variabel independen yang dianalisis yaitu variabel $\left(\mathrm{X}_{1}, \mathrm{X}_{2}\right.$, dan $\left.\mathrm{X}_{3}\right)$ memberikan pengaruh positif terhadap variabel dependen ( $\mathrm{Y}$ ) yaitu keputusan pembelian pada kawasan wisata Anjungan Pantai Talise. Agar lebih jelasnya penjelasan bentuk persamaan tersebut dapat dilihat berikut ini:

1. Nilai konstanta sebesar 0,320 artinya jika variable citra yang terdiri dari (kekuatan, keunikan, keunggulan) bernilai 0 atau konstan, maka variabel dependen (keputusan pembelian) nilainya sebesar 0,320. Setiap ada kenaikan pada variabel independen sebesar satu satuan maka akan meningkatkan variabel dependen sebesar nilai koefisiensi beta masing-masing variabel independen dikalikan dengan besarnya kenaikan yang terjadi.

2. Koefisien regresi kekuatan sebesar 0,327, artinya bahwa pengaruh variabel kekuatan terhadap keputusan pembelian di kawasan wisata Anjungan Pantai Talise adalah bersifat positif dan jika skor variabel kekuatan meningkat maka variabel keputusan pembelian juga akan meningkat.

3. Koefisien regresi keunikan 0,257, artinya bahwa pengaruh variabel keunikan terhadap variabel keputusan pembelian adalah bersifat positif dan jika skor variabel keunikan meningkat maka variabel keputusan pembelian juga akan meningkat.

4. Koefisien regresi keunggulan 0,301, artinya bahwa pengaruh variabelkeunggulan terhadap variabel keputusan pembelian adalah bersifat positif dan jika skor variabel keunggulan meningkat maka variabel keputusan pembelian juga akan meningkat.

Tahap selanjutnya adalah menguji signifikan hubungan atau uji $\mathrm{F}$ antar variabel penelitian yaitu kekuatan, keunikan, dan keunggulan terhadap keputusan pembelian. Berdasarkan tabel 2, diperoleh angka signifikan $\mathrm{F}$ sebesar 0,000 . angka $0,000<0,05$ hal ini berarti terdapat pengaruh secara simultan pada variabel kekuatan, keunikan, dan keunggulan terhadap keputusan pembelian pada kawasan wisata Anjungan Pantai Talise di Kota Palu.Oleh karena itu hipotesis 1 diterima.

Pengujian hipotesis secara parsial adalah untuk mengetahui apakah variabel kekuatan, keunikan, dan keunggulan secara parsial berpengaruh secara positif dan signifikan terhadap keputusan pembelian pada kawasan wisata Anjungan Pantai Talise di Kota Palu. Adapun hasil pengujian secara parsial untuk setiap variabel independen terhadap variabel dependen. Berdasarkan tabel 2, hasil pengujian SPSS diperoleh hasil angka signifikan $t$ sebesar 0,000 . Angka $0,000<0,05$ hal ini berarti terdapat pengaruh variabel kekuatan terhadap keputusan pembelian pada kawasan wisata Anjungan Pantai Talise di Kota Palu. Oleh karena itu hipotesis 2 diterima. Selanjutnya, berdasarkan tabel 2, hasil pengujian SPSS diperoleh hasil angka signifikan t sebesar 0,020. Angka 0,020 < 0,05 hal ini berarti terdapat pengaruh variabel keunikan terhadap keputusan pembelian pada kawasan wisata Anjungan Pantai Talise di Kota Palu. Oleh karena itu 
hipotesis 3 diterima. Terakhir, berdasarkan tabel 2 dimana hasil pengujian SPSS diperoleh hasil angka signifikan t sebesar 0,019. Angka $0,019<0,05$ hal ini berarti terdapat pengaruh variabel keunggulan terhadap keputusan pembelian pada kawasan wisata Anjungan Pantai Talise di Kota Palu. Oleh karena itu hipotesis 4 dapat diterima.

\section{Pembahasan}

Hasil penelitian ini menunjukan bahwa variabel kekuatan berpengaruh positif dan signifikan terhadap keputusan pembelian. Adapun indikator-indikator yang digunakan untuk mengukur variabel kekuatan adalah harga yang terjangkau, penggunaan bumbu khas, dan mudah dijumpai. Indikator yang terdapat didalam variabel kekuatan sesuai dengan apa yang dirasakan oleh responden dimana dari semua indikator terdapat beberapa yang sesuai dengan apa yang dirasakan oleh responden seperti kuliner tradisional khas kaili sangat mudah dijumpai di Kota Palu, dimana untuk kuliner tradisional ini sangat mudah ditemukan pada daerah kawasan Kota Palu salah satunya terdapat rumah makan yang menyediakan suatu menu utama yaitu kaledo, dimana rumah makan ini terdapat di sepanjang jalan Ponegoro dan ada juga yang terletak di daerah desa Loli. Selain itu untuk kuliner tradisional jenis lainnya dapat ditemukan di jalan Bantilan dan Tembang. Selanjutnya yaitu indikator harga kuliner tradisional khas kaili sangat terjangkau, dimana harga dari kuliner tradisional khas kaili tidaklah sangat mahal dari beberapa kuliner tradisional khas kaili yang memiliki harga tertinggi yaitu kaledo dan utadada selain dari kedua jenis kuliner tersebut harganya sangat terjangkau kisaran dari 5.000 rupiah hingga 10.000 .

Hal ini membuktikan bahwa setiap indikator yang terdapat pada variabel kekuatan sesuai dengan apa yang dilihat atau dirasakan oleh responden, selain itu pengaruh variabel kekuatan terhadap keputusan pembelian dapat dilihat dengan nilai signifikansi yang didapatkan oleh variabel kekuatan yaitu sebesar 0,000 dan besar pengaruh yang dimiliki oleh variabel kekuatan terhadap keputusan pembelian yaitu sebesar $45,5 \%$.

Hasil penelitian ini sejalan dengan penelitian sebelumnya yaitu penelitian Aniek Fatlahah (2013) yang menyatakan bahwa komponen citra merek yang terdiri dari salah satunya kekuatan merek dapat berpengaruh terhadapa keputusan pembelian.

Variabel keunikan merupakan salah satu variabel dari citra dimana yang memiliki pengaruh terhadap keputusan pembelian, adapun indikator untuk mengukur variabel keunikan adalah nama makanan yang unik, tampilan makanan yang menarik. Indikator yang terdapat pada variabel keunikan sejalan dengan pemikiran responden dimana rata-rata responden mengakui bahwa makanan tradisional khas kaili memang memiliki nama-nama makanan yang unik yang di ambil dari bahasa daerah suku kaili.

Hal ini membuktikan bahwa variabel keunikan yang terdiri dari beberapa indikator memiliki pengaruh terhadap keputusan pembelian, sesuai dengan pernyataan diatas dimana variabel keunikan memiliki pengaruh terhadap keputusan pembelian maka diperkuat dengan nilai signifikansi yang di dapatkan oleh variabel keunikan yaitu sebesar 0,020 dengan besar pengaruh yang dimiliki variabel keunikan terhadap keputusan pembelian sebesar 25,7\%. Berdasarkan hasil penelitian ini, dimana indikator yang digunakan untuk mengukur variabel keunikan memiliki pengaruh terhadap keputusan pembelian.

Penelitian ini sejalan dengan penelitian yang dilakukan oleh Prima Conny, et, al (2014) yang menegaskan bahwa citra merek berpengaruh signifikan terhadap keputusan pembelian, dengan citra merek yang baik dapat menciptakan konsumen untuk mencoba dan melakukan suatu pembelian.

Hasil penelitian ini menunjukan bahwa variabel keunggulan berpengaruh positif dan signifikan terhadap keputusan pembelian.Adapun indikator yang terdapatpada variabel keunggulan yaitu sebuah kuliner khas Kota Palu, cita rasa yang khas, makanan yang sederhana. Terdapat beberpa indikator yang menjadi pengukur untuk variabel keunggulan, responden lebih memperhatikan indikator kuliner tradisional khas kaili adalah sebuah kuliner khas dari Kota Palu dan kuliner tradisional khas kaili adalah sebuah kuliner yang sederhan. Berdasarkan hal ini membuktikan bahwa kuliner tradisional khas kaili sebuah kuliner khas daerah Kota Palu dan sebuah kuliner yang sederhana. Untuk melihat seberapa besar pengaruh variabel keunggulan terhadap keputusan pembelian dapat dilihat pada nilai signifikansi yang 
memiliki nilai sebesar 0,019 , nilai ini menunjukkan bahwa variabel keunggulan memiliki pengaruh yang baik terhadap keputusan pembelian dan indikator yang masuk pada variabel keunggulan sangat sesuai dengan apa yang dirasakan oleh responden, selain itu besar pengaruh yang didapatkan oleh variabel keunggulan yaitu sebesar $25,1 \%$.

Hasil penelitian ini sejalan dengan teori di kemukakan oleh Imelda Yuliana (2016) yang menyatakan bahwa keputusan pembelian konsumen dibentuk melalui variabel citra merek yang dimana citra merek dapat membuat pengaruh yang baik terhadap keputusan pembelian dengan cara memperhatikan faktor citra merek dengan berusha menciptakan kesan positif pada konsumen.

\section{PENUTUP}

Berdasarkan hasil penelitian yang telah dijabarkan, maka diperoleh kesimpulan mengenai pengaruh citra kuliner tradisional khas kaili terhadap keputusan pembelian pada kawasan wisata Anjungan Pantai Talise:

1. Variabel dimensi citra yang terdiri dari kekuatan, keunikan, dan keunggulan secara serempak berpengaruh signifikan terhadap keputusan pembelian pada kawasan wisata Anjungan Pantai Talise di Kota Palu.

2. Variabel kekuatan secara parsial berpengaruh signifikan terhadap keputusan pembelian pada kawasan wisata Anjungan Pantai Talise di Kota Palu.

3. Variabel keunikan secara parsial berpengaruh signifikan terhadapkeputusan pembelian pada kawasan wisata Anjungan Pantai Talise di Kota Palu.

4. Variabel keunggulan secara parsial berpengaruh signifikan terhadap keputusan pembelian pada kawasan wisata Anjungan Pantai Talise di Kota Palu.

Berdasarkan kesimpulan yang telah diuraikan sebelumnya, maka saran-saran yang tepat menyangkut kegunaan penelitian ini dapat diuraikan sebagai berikut:

1. Kepada peneliti selanjutnya disarankan untuk menggunakan variabel lain seperti variabel loyalitas, keputusan berkunjung kembali, dan kepuasan, selain yang digunakan dalam penelitian ini, sehingga lebih dapat mengulas masalah-masalah yang ada di kawasan wisata Anjungan Pantai Talise.

2. Selain itu, berdasarkan hasil penelitian yang didapatkan dimana citra berpengruh terhadap keputusan pembelian pada kawasan wisata Anjungan Pantai Talise. Maka dari itu di sarankan kepada pihak pengelolah dan pedagag yang berada di kawasa wisata Anjungan Pantai Talise harus dapat mempertahankan citra dari kawasan wisata tersebut yang termasuk di dalamnya kekuatan, keunikan, dan keunggulan.

3. Bagi pihak pengelolah kawasan wisata Anjungan Pantai Talise di sarankan untuk tetap mempertahankan kawasan wisata tersebut karena untuk wilayah Kota Palu belum ada sama sekali kawasan wisata yang menyediakan wisata kuliner tradisional dan sebuah wisata yang menjadi lahan edukasi untuk remaja dan masyarakat Kota Palu, untuk itu dengan mempertahankan kawasan wisata Anjungan Pantai Talise akan mendapat dampak yang positif bagi Kota Palu dan Masyarakatnya karena dapat memperkenalkan makanan tradisional khas daerah Kota Palu serta dapat mengembangkan pengetahuan untuk para pengunjung dan masyarakat Kota Palu.

\section{REFERENSI}

Andayani, (2013). Manajemen Pemasaran Pariwisata, , Graha Ilmu:Yogyakarta

Aniek Fatlahah, (2013). Pengaruh Kualitas Produk dan Citra Merek Terhadap Keputusan Pembelian EsKrim Wall's Magnum. Jurnal Ilmu Manajemen, Volume 1 Nomor 2 Maret 2013.

Boyd, et al, (2000). Manajemen Pemasaran (Suatu Pendekatan Strategi Dengan Orientasi Global). Edisi 1, Erlangga: Jakarta 
Ghozali, Imam. (2013). Aplikasi Analisis Multivariat Dengan Program IBM SPSS 21, Edisi 7. Universitas Diponegoro: Semarang.

Imelda Yuliana, (2016). Pengaruh Kualitas Layanan, Citra Merek, dan Lokasi Terhadap Keputusan Pembelian. Jurnal Ilmu dan Riset Manajemen, Vol 5, No 6, Juni 2016.

Kotler dan Keller, (2007). Manajemen Pemasaran edisi 12, jilid 1.. PT. Indeks: Jakarta Barat

Kotler dan Keller, (2005). Manajemen Pemasaran edisi 2, jilid 1. PT. Indeks Kelompok Gramedia:. Jakarta

Prasiasa, Dewa Putu Oka, (2013). Destinasi Pariwisata Berbasis Masyarakat. Salemba Humanika. Jakarta.

Prima Conny, et, al, (2014). Pengaruh Citra Merek Terhadap Word of mouth dan Keputusan Pembelian : Survei pada konsumen Dapoer Mie Galau Jalan Selorejo 83 Malang. Jurnal Administrasi Bisnis (JAB), Volume, 10, No, 1 Mei 2014.

Sutisna, (2003). Perilaku Konsumen dan Komunikasi Pemasaran, PT. Remaja Rosdakarya, Jakarta. Sugiyono, (2012). Metode Penelitian., Alfabeta: Bandung Sunyoto, (2012). Konsep Dasar Pemasaran dan Perilaku Konsumen, PT. BUKU SERU: Jakarta, Sunyoto, Danang. (2013). Metodologi Penelitian Akuntansi. PT Refika Aditama: Bandung. Suryani, (2008). Perilaku Konsumen "Implikasi pada strategi pemasaran” GrahaIlmu:Yogyakarta, 